\title{
REGIMENTO INTERNO DAS ESCOLAS PÚBLICAS DA CORTE DE 1883: uma síntese da educação imperial ${ }^{1}$
}

André Paulo Castanha ${ }^{2}$

\section{Apresentação}

O objetivo do presente texto é apresentar e analisar o Regimento Interno das Escolas Públicas da Corte de 1883. Trata-se de uma lei interna às escolas, posta em execução pela Decisão n. 77 do Ministério do Império, de 6 de novembro de 1883, passando a ser obrigatório nas escolas a partir do início do ano de 1884. É um documento síntese da educação imperial, pouquíssimo explorado pelos historiadores da educação.

O documento é síntese porque expressa tradição e modernidade na organização da escola primária imperial. A tradição está na grande ênfase aos valores morais e cívicos que deveriam ser difundidos pela escola e no controle do trabalho dos professores. A modernidade está expressa no processo de construção do regimento, na difusão do método intuitivo, na articulação entre leitura e escrita, na articulação entre os conteúdos escolares.

Segundo Castanha (2011a), em 1882, o Ministro do Império, Rodolfo Epifânio de Souza Dantas enfatizou, no seu relatório, que somente a pedagogia moderna poderia despertar nos meninos os "mais vivos estímulos da sua natureza", pois eles tinham a necessidade "de ver, de sentir, de esquadrinhar, de exprimir, de executar, de inventar, achando, comparando, associando, imitando, filiando coisas a coisas, fenômenos a fenômenos, realidades a realidades". Além de defender um ensino com base na pedagogia moderna, das lições de coisas, argumentou, perante os deputados, que o governo deveria "executar rigorosamente, na Capital do Império", tal programa de ensino e impor o ensino obrigatório a todas as "famílias de todas as crenças", ou seja, secularizar a escola, deixando sob responsabilidade da autoridade paterna o ensino religioso.

Enquanto Souza Dantas propagava suas iniciativas em favor de uma instrução pública moderna, a Câmara dos deputados nomeava uma comissão para emitir parecer sobre o projeto de reforma apresentado por Carlos Leôncio de Carvalho, em 19 de abril de 1879, o qual havia sido encaminhado ao legislativo para apreciação, ainda em abril de 1880. Os deputados escolhidos foram Rui Barbosa (bacharel em direito eleito pela Bahia), Thomaz do Bomfim Espínola (médico eleito por Alagoas) e Ulysses Machado Pereira Vianna (bacharel em direito eleito por Pernambuco), cabendo ao primeiro a relatoria dos trabalhos da comissão. O parecer elaborado sobre o ensino primário era denso e detalhista e abordava algumas questões ligadas à estatística escolar no Brasil e em outros países. No parecer, a comissão de instrução defendeu o seguinte:

Uma reforma radical do ensino público é a primeira de todas as necessidades da pátria, amesquinhada pelo desprezo da cultura científica e pela insigne deseducação do povo. Sob esta invocação conservadores e liberais, no Brasil, podem reunir-se em um terreno neutro: o de uma reforma que não transija com a rotina. Num país onde o ensino não existe, quem disser que é conservador em matéria de ensino volteia as costas ao futuro, e desposa os interesses da ignorância (BARBOSA, 1982, p. 143. Grifo do autor).

No parecer, a comissão defendeu a criação do Ministério da Instrução Pública, a obrigatoriedade escolar, a escola leiga, entre outros. A partir dos pareceres, a comissão apresentou um projeto de reforma da instrução pública, em 12 de setembro de 1882 . O projeto era amplo e abordava vários temas, tais como: a liberdade de ensino, secularidade da escola, instrução obrigatória, as escolas normais, museu pedagógico, administração da 
instrução pública, o fundo escolar, a criação dos conselhos escolares paroquiais, a higiene escolar. Enfim, era um projeto consistente, que reunia muitas das ideias que estavam em voga a partir de 1870.

$\mathrm{Na}$ década de 1880, as questões ligadas à reforma do sistema eleitoral e da substituição do trabalho servil foram mais relevantes que questão da instrução pública. Apesar de amplamente debatida, poucas ações foram efetivadas. A última ação concreta de caráter geral, que teve impacto direto na instrução primária, foi o Regimento Interno das Escolas Públicas da Corte de 1883. Por isso, não tenho dúvidas de que a disponibilização do documento na íntegra, contribuirá efetivamente, para o desenvolvimento de estudos e pesquisas em história da educação imperial e poderá estimular a retomada dos estudos da legislação educacional.

Atualmente, os estudos envolvendo a legislação educacional, em sua perspectiva histórica, são pouco expressivos no campo da história da educação. As leis estão sendo relegados ao segundo plano, em virtude das inovações/modismos introduzidas na historiografia educacional. Conforme indiquei em estudo anterior "as leis relacionadas à educação constituem-se como fontes históricas documentais da mais alta importância para se produzirem conhecimentos histórico-educativos". Todavia, análise da legislação não pode ser feita de "forma mecânica, ou seja, a lei pela lei, sem (ou só) estabelecer ligações entre o poder político hegemônico, sem fazer conexões entre a legislação educacional e o projeto político social ou a própria prática social, sem considerar as reações (incorporações/resistências) da sociedade ou setores diretamente afetados pelas medidas legais etc." (CASTANHA, 2011, p. 319-20). As leis são criações humanas, produzidas nos embates entre as forças políticas e sociais e expressam "sonhos, desejos, paixões e interesses", os quais estão refletidos nas ações indivíduos e na gerência e administração do Estado. (Idem. p, 317).

Precisamos compreender historicamente os limites das leis, perceber avanços e retrocessos, rupturas e continuidades. Para tanto, temos que retomar os estudos da legislação educacional, enquanto fonte histórica. E esse é o principal objetivo do presente texto. Quero enfatizar que esta análise e interpretação do documento, não substitui a leitura do próprio Regimento. Ao lê-lo, o leitor poderá explorar outras temáticas e tirar suas próprias conclusões.

\section{O Processo de Construção do Regimento Interno das Escolas}

Logo que assumiu a função de inspetor de instrução pública da Corte, Antonio Herculano de Souza Bandeira Filho implementou uma série de ações para reorganizar a instrução pública. Na sua avaliação, "o regime das escolas se caracterizava pela completa ausência de regra ou norma geral do ensino. Cada professor julgava-se com o direito de ensinar como lhe aprazia e como lhe convinha; alterava, aumentando ou diminuindo, o programa oficial, de modo mais arbitrário" (MUNICÍPIO da Corte. Relatório do Inspetor Souza Bandeira, de 1884. p. 13). O regimento interno que estava em vigor era o de 20 de outubro de 1855, complementado pelo programa provisório das escolas aprovado em 9 de janeiro de 1882, o qual não estabeleceu orientações metodológicas mais concretas.

A constatação de plena liberdade dos professores, a que chegou o inspetor Souza Bandeira, se deu, a partir da decretação da plena liberdade de ensino, proposta pela reforma Leôncio de Carvalho de 19 de abril de 1879. A confusão aumentou ainda mais, quando o governo criou a Escola Normal da Corte, pelo decreto n. 7684, de 6 de março de 1880, atribuindo também aos professores da referida escola a responsabilidade pela inspeção das escolas primárias. Tal fato gerou uma superposição de poderes no sistema de 
inspeção, entre os delegados de distrito e os professores da Escola Normal, produziram impactos negativos no cotidiano escolar, como bem indicou Souza Bandeira.

Para reverter o quadro de liberdade e desorganização presente no interior da maioria das salas de aula, o inspetor entendeu que deveria "começar por estabelecer uma norma de ensino obrigatória para todos os professores" e, assim, iniciou os trabalhos para reorganizar o regimento interno das escolas primárias da Corte. Pelo descrito no seu relatório, os passo foram os seguintes: $1^{\circ}$ - encaminhou uma circular aos delegados, recomendando que estes solicitassem dos professores sugestões para reorganizar o regimento interno; $2^{\circ}$ - solicitou ao diretor da Escola Normal que ouvisse os professores sobre a matéria. As respostas não foram animadoras, pois, os professores da Escola Normal não se manifestaram. Entre os professores primários, 47 não responderam, 27 informaram que estavam satisfeitos com o regimento anterior; dentre os 20 que responderam, 15 apresentaram análises sofríveis, e 5 "apresentaram trabalhos que revelavam estudo e foram mais ou menos tomados em consideração". $3^{\circ}$ - depois de redigida a primeira versão, a mesma foi encaminhada aos membros do conselho diretor e outras pessoas que poderiam emitir parecer e sugestões; $4^{\circ}$ - feita uma nova revisão o texto foi apreciado e aprovado pelo conselho diretor; $5^{\circ}$ - o regimento foi adotado em caráter experimental em algumas escolas por três meses; $6^{\circ}$ - ao findar o período experimental, o inspetor reuniu-se com os professores e fizeram as modificações que a experiência demonstrou; $7^{\circ}$ - a proposta foi encaminhada ao ministro para aprovação final (MUNICÍPIO da Corte. Relatório do Inspetor Souza Bandeira de 1884, p. 13-4). Percebe-se, pelo descrito acima, que a proposta resultou da intervenção de várias pessoas, e, dentre elas, muitas estavam preocupadas com a reorganização da escola primária e, consequentemente, com a qualidade da educação.

O regimento foi introduzido em todas as escolas públicas da Corte no início do ano letivo de 1884. Em ofício circular aos delegados de distrito, no início daquele ano, o inspetor Souza Bandeira fez a seguinte revelação sobre o regimento:

Com ele teve-se em vista suprir as lacunas do regimento de 1855, o qual, acomodado às disposições do Decreto de 17 de fevereiro de 1854, estava em muitos pontos derrogado por atos posteriores, os Decretos de 18 de janeiro de 1877 e 19 de abril de 1879. Consolidando todos esses atos, na parte referente a boa direção das escolas, o novo regimento habilitou o professor a conhecer com precisão as exigências que lhe são feitas pela legislação em vigor. Recomendo particularmente a V.S., que faça observar com cuidado o capítulo relativo ao plano de ensino. Nesta matéria o novo regimento propõe-se a satisfazer a necessidade de uniformizar o ensino nas escolas públicas, encaminhando-o no sentido dos melhoramentos realizáveis entre nós na parte metodológica (MUNICÍPIO da Corte. Relatório do Inspetor Souza Bandeira Filho, de 1884, p. 15).

Diante do exposto, ficou explícito que um dos principais alvos do regimento de 1883 era uniformizar o plano de ensino das escolas e, sobretudo, criar mecanismos para fazer com que os professores pusessem-no em execução.

\section{A Organização Administrativa e Didática das Escolas}

O regimento estabeleceu uma grande quantidade de atividades burocráticas para serem cumpridas pelos professores. Tais atividades certamente consumiram várias horas semanais dos professores, que poderiam ser dedicadas ao trabalho didático, além de outras tantas de seus momentos de descanso. Do conjunto de livros e registros que faziam parte 
da escrituração escolar, previstos entre os artigos $6^{\circ}$ e 12 destaco os seguintes: catálogo da biblioteca - era de inteira responsabilidade do professor organizar o catálogo da biblioteca, conforme determinava o regulamento das bibliotecas escolares; livro da caixa econômica escolar - o controle do livro da caixa econômica escolar era outra atividade que necessitava de muito cuidado e atenção por parte dos professores, conforme exigia o regulamento; livro de matrículas - era o documento mais importante da escola e também exigia muito zelo por parte dos professores, pois além do registro de todos os dados dos alunos, o professor deveria registrar, na coluna observações, 0 comportamento/desenvolvimento de cada um deles. Tal coluna era uma espécie de boletim individual; livro de inventário era o mais tranquilo de todos, pois as escolas não contavam com muitos móveis e utensílios; livro de visitas - o preenchimento do livro de visitas era de responsabilidade dos visitantes, mas mesmo assim tomava o tempo dos professores, pois certamente, eles corriam para ler as observações, logo que as visitas saíam. Ao ler as anotações dos visitadores, os professores poderiam ficar animados ou angustiados e, tal estado de espírito, certamente, interferia no trabalho didático. Até o momento, não tive acesso a tais livros, mas espero tomá-los como fontes em estudos futuros. Acredito que tais livros guardam informações preciosas sobre o cotidiano das escolas primárias do século XIX.

Ainda reacionadas à burocratização e hierarquização da estrutura escolar merece destaque o artigo 88, ao impor que todas as comunicações escritas entre os professores e o inspetor teriam que ser mediadas pelo delegado de distrito. Os delegados eram os responsáveis diretos pela implementação do regimento interno nas escolas, por isso, poderiam impor aos professores a adoção das medidas que entendessem necessárias para ajustar a organização escolar à nova proposta.

Quanto às matrículas, os artigos 13, 14 e 15 revelam informações importantes: 1 as idades limites para ingresso e saída da escola (5 a 15) permaneciam as mesmas instituídas pelo Regulamento de 17 de fevereiro de 1854 - Reforma Coutto Ferraz. Não se adotou, portanto, a idade instituída pelo decreto de Leôncio de Carvalho entre 7 e 14 anos; 2 - manteve também os mesmos critérios, ao exigir comprovante de vacinação, ao excluir os portadores de moléstias contagiosas. A novidade foi a inclusão da palavra repugnante. Na época não havia mais restrição às crianças escravas, devido à aprovação doa Lei do Ventre Livre, de 1871; 3 - o regimento estabeleceu cinco períodos de ingresso na escola durante o ano: $2^{\mathrm{a}}$ quinzena de janeiro e a $1^{\mathrm{a}}$ dos meses de março, maio, julho e setembro. $\mathrm{O}$ professor fazia a matrícula provisória, depois organizava uma lista e encaminhava para a aprovação do delegado. Este emitia uma guia, autorizando o professor a fazer a matrícula definitiva. Ao olharmos para os períodos de ingresso, podemos concluir que não havia uma unidade na classe inicial e tal situação dificultava em muito o trabalho dos professores; 4 no caso de alunos que vinham transferidos de outras escolas, o professor avaliava e incluíaos na classe correspondente ao seu nível de conhecimento.

$\mathrm{O}$ regimento manteve o mesmo calendário escolar instituído pelo regulamento de 1877, mas reduziu o número de dias definidos como feriados durante o ano, conforme indicado nos artigos 22 e 23 . O horário das aulas e a distribuição das atividades diárias foram definidas entre os artigos 24 e 29. O regimento adotou o horário proposto pela Reforma Leôncio de Carvalho, com horários diferenciados entre verão e inverno. A novidade foi a dispensa das aulas de sábado à tarde. Mantiveram-se às seis horas diárias de aula, mas, ao invés de um intervalo de uma hora passou a ter dois intervalos de meia hora cada. Pela proposta, tais espaços ainda deveriam ser utilizados para exercícios físicos e de costura, todavia já estava mais clara a ideia de recreação. A distribuição do horário diário provavelmente, era a seguinte: das 8 1/2 às 10 1/2, aulas; das 10 1/2 às 11, intervalo; das 11 às 
12 1/2, aula; das 12 1/2 às 13 intervalo; e, das 13 até 14 1/2, aula. Isso, para o verão. Ao considerar essa formulação como um provável horário, chegaremos à conclusão que os alunos da $1^{\text {a }}$ classe, conforme estabelecido pelo artigo 26 , estavam dispensados a partir das $12 \frac{1}{2}$. O regimento não apresentou uma sugestão da distribuição dos conteúdos durante os dias da semana, apenas estabeleceu que tal horário seria definido no início de cada ano pela inspetoria geral.

$\mathrm{O}$ artigo 30 determinava que, em cada escola tivesse uma tabuleta com as armas imperiais, indicando o sexo para qual era destinada. Segundo o artigo 31, a mobília que cada escola deveria ter era bem simples, tais como: um mapa do Brasil e outro do sistema métrico decimal; um relógio de parede; um armário para guarda dos livros e objetos de trabalho; uma mesa com estrado e uma cadeira de braços para o professor; duas cadeiras de sobressalente; o número de bancos e carteiras suficientes para os alunos matriculados; os quadros pretos indispensáveis; os cabides necessários para os chapéus. Todos esses utensílios deveriam ser fornecidos pelo Estado. Conforme indicava o artigo 32, o Estado também deveria fornecer os objetos necessários para a prática ou auxílio do método intuitivo, sempre que fosse possível fazer aquisição.

O currículo estabelecido pelo regimento, no seu artigo $1^{\circ}$, era o seguinte: instrução moral e religiosa; leitura; escrita; noções essenciais de gramática; princípios elementares de aritmética; sistema métrico decimal; noções de história e geografia do Brasil; elementos de desenho linear; rudimentos de música; exercícios de ginástica. Para as escolas do sexo feminino acrescentou a costura. Ao compararmos com o currículo proposto pela reforma de Leôncio de Carvalho, veremos que foi omitido as "noções de coisas" do quadro de disciplinas, incorporando-a como procedimento metodológico a ser utilizado no ensino de diversos conteúdos. Quanto à presença dos professores e adjuntos em sala de aula, ou seja, os auxiliares dos professores titulares, o regimento seguiu as determinações do Regulamento de 18 de janeiro de 1877, o qual garantiu um professor adjunto para as escolas com mais de 50, 2 para as com mais de 100, e 3 para as com mais de 150 alunos frequentes. $\mathrm{O}$ artigo 18 estabeleceu em 200, o número máximo de alunos que poderiam ser matriculados. Já, o artigo 20 determinou que, quando a escola contasse com 150 alunos frequentes, não seriam admitidas novas matrículas.

Quanto à organização das classes, o regimento normatizou as subdivisões entre os artigos 37 e 44, apresentando alguns avanços significativos, comparativamente com os documentos anteriores. Enquanto o regimento de 1855 não estabeleceu divisões entre os alunos do $1^{\circ}$ grau, o programa provisório de 1882 determinou que os alunos fossem divididos em seis classes, somente para cumprir o programa do conteúdo obrigatório. A partir de 1884, as escolas seriam organizadas em três classes, possibilitando, no entanto, que na $1^{a}$ classe fossem feitas mais divisões de acordo com os níveis de compreensão dos alunos, ou seja, poderia haver a classe dos que estavam conhecendo as letras, dos que estavam formando sílabas e dos que já estavam formando palavras. Todavia, a maior inovação se deu na imposição de que, nos trabalhos nas $2^{\mathrm{a}}$ e $3^{\mathrm{a}}$ classes, o conteúdo deveria ser ministrado simultaneamente para todos os alunos da classe. O método simultâneo havia sido introduzido oficialmente pelo Regulamento de 1854, mas até então ainda era muito usado o método individual. Segundo o texto, os alunos não poderiam passar de uma classe para a outra, enquanto não dominassem os conhecimentos específicos daquele nível, no entanto, não define como seria o processo de avaliação dos conhecimentos para passar de uma classe para outros. O regimento possibilitava a utilização, por parte do professor, de alunos da $3^{\mathrm{a}}$ classe para tomar a lição dos da $1^{\mathrm{a}}$ classe, porém indicava uma fórmula um tanto complicada de organização das carteiras nas escolas. O fato de o regimento possibilitar o uso de alunos da $3^{\mathrm{a}}$ classe, para tomar lições dos da $1^{\mathrm{a}}$ classe, evidencia que 
ainda no final do Império, havia resquícios da prática do método Lancaster no cotidiano escolar.

O regimento previa subdivisões na $1^{a}$ classe pelas dificuldades que o processo de alfabetização acarretava e, também porque era permitida a entrada de crianças em vários períodos do ano. Quanto ao aprendizado específico da $1^{\text {a }}$ classe, previstos no artigo 46, o regimento determinava o seguinte: os conhecimentos de ensino religioso estavam restritos às principais orações, as quais seriam ensinadas de forma coletiva, no início e final de cada dia letivo. Sobre o ensino de leitura, o texto menciona três métodos: o alfabético, o fonético e o de articulação. O documento recomendava que fosse substituído o método alfabético, principalmente pelo fonético ou pelo de articulação. Tenho dúvidas sobre os fundamentos do método de articulação e não consegui encontrar informações concretas sobre seus mecanismos de funcionamento. Ao que parece não era a junção do alfabético com o fonético, pois o texto sugeria que o professor que se julgasse em condições poderia "combinar os três métodos, a fim de aproveitar as vantagens e obviar os defeitos". O Regimento recomendava que os professores tornassem o ensino de leitura algo prazeroso e articulasse com o ensino da escrita, utilizando-se da lousa para demonstrar as linhas retas, perpendiculares, curvas etc., e acostumar os alunos no uso do giz e da ardósia e, assim associar os conceitos do desenho linear com a escrita e a leitura. Para auxiliar no ensino da leitura e escrita, os alunos deveriam praticar exercícios verbais, reproduzindo pequenas narrações, fábulas, versos, fazendo, ao final, as correções necessárias dos erros mais grosseiros. Quanto ao ensino da matemática, o regimento menciona o uso do contador mecânico, provavelmente se referia ao ábaco, o qual deveria ser utilizado por todos os alunos para fixar os números e introduzir os conceitos das quatro operações fundamentais da aritmética. Os exercícios práticos deveriam ser no quadro preto. $\mathrm{O}$ ensino do sistema métrico deveria ter por base os princípios das lições de coisas, desenvolvendo exercícios práticos com o metro e a balança. De modo geral a proposta apresentava uma boa articulação entre leitura, escrita, fala e raciocínio lógico, estimulando o uso de objetos concretos e enfatizando a prática de exercícios.

Como previa o artigo 47, na segunda classe, ou intermediária haveria um aprofundamento de todos os conteúdos, reforçando a relação entre leitura e escrita e expressão oral. Estas atividades seriam auxiliadas pelo uso do método das lições de coisas, pela repetição das atividades, pela realização de ditados e da memorização de determinadas palavras, versos etc. Também seria constante o uso do quadro preto e da ardósia para o ensino das figuras geométricas, para a prática da escrita, desenvolver exercícios relacionados às quatro operações da aritmética. Na matemática, além dos exercícios práticos, os alunos seriam estimulados a realizar cálculos mentais e a resolver problemas simples de situações da vida cotidiana, aproveitando para isso os dispêndios das pessoas feitos com bebidas, tabaco. Essas serviriam como base para discutir os valores morais com as crianças.

$\mathrm{O}$ artigo 48 normatizou os trabalhos da $3^{\mathrm{a}}$ classe. Nela, os alunos deveriam aprender os mandamentos da Lei de Deus, mandamento da Igreja, os Sacramentos. A leitura seria corrente e repetida evidenciando a entonação e a pontuação. Ao praticar a leitura, o professor deveria aproveitar para desenvolver atividades visando à interpretação do texto, ideias principais e secundárias. A prática da escrita era feita com o uso de tinta em papel, através de cópias, ditados e redações sobre temas livres. Nas atividades de leitura e escrita, seriam enfatizados os aspectos da gramática e praticada a memorização de poemas clássicos. Na matemática, permaneciam os exercícios de aritmética relacionados às quatro operações fundamentais, com a inclusão de números decimais, de frações, a resolução de problemas sobre pesos e medidas. $\mathrm{Na} 3^{\mathrm{a}}$ classe inseriram-se os estudos de geografia. $\mathrm{O}$ 
professor deveria principiar pelos pontos cardeais, tendo como referência a localização da escola, depois, da freguesia, Corte etc. até chegar à compreensão da estrutura política e administrativa do Império. Aliado a isso se ensinariam as características geográficas das várias regiões. A história seria trabalhada paralela à geografia, sem a indicação de conteúdos específicos.

O ensino dos conteúdos de caráter morais e cívicos era central na escola primária do século XIX. Conforme previa o artigo 49, os professores deveriam enfatizar o amor de Deus para com seu povo, a prática das virtudes cristãs, o amor pela pátria, o respeito pelas autoridades, leis, sempre que possível destacando as ações dos grandes homens, estudando a biografia dos grandes patriotas. Todavia, a principal maneira de incutir os valores morais e cívicos nos alunos, segundo o texto do regimento, era o exemplo vivo do professor. Ao relacionar-se de forma cordial com os alunos, na forma como recebia as autoridades de inspeção ou os familiares na escola, nos comentários que fazia após as visitas se retirarem, na sua vida na comunidade etc., o professor tornava-se exemplo concreto para os alunos. $\mathrm{O}$ poder exercido pelo professor sobre os alunos explica o rigor adotado pelas autoridades, via legislação, para controlar o ingresso no magistério público.

A prática de costura era obrigatória em todas as classes das escolas femininas, conforme expressa o artigo 50. Segundo o artigo 51, nas escolas femininas e masculinas também deveriam ser praticados exercícios físicos e ministrado aulas de música. Tais disciplinas deveriam ser ministradas durante os dois intervalos previstos no período letivo diário. A introdução da disciplina de ginástica, hoje educação física, sofreu uma forte resistência no período, principalmente nas escolas femininas, tanto primárias, como na escola normal. Os fundamentos para a resistência eram basicamente morais. Uma das evidências dessa resistência está no fato de o regimento prever honrarias aos professores que conseguissem desenvolver adequadamente as disciplinas de ginástica e música.

Chamo a atenção para o artigo 52, que manteve o controle efetivo do Estado sobre os livros didáticos adotados nas escolas públicas. Ao controlar os livros, controlava-se a entrada de ideias perigosas nas escolas. Já o artigo 53 esclareceu que os alunos acatólicos só teriam direito à dispensa de frequência nas aulas de ensino religioso, (como previa a Reforma Leôncio de Carvalho), caso tivessem feito expressa solicitação no momento da matrícula. Todavia, o regimento não indicou qualquer privilégio para tais alunos usufruírem do benefício.

O sistema de exames finais instituído pelo regimento de 1883 , normatizado entre os artigos 68 e 77, era muito semelhante aos exames praticados com os professores nos concursos públicos. Quando o professor entendia que determinados alunos estavam em condições de responder às questões propostas pela banca indicava-os para os exames finais. Os alunos realizavam provas escritas e orais. Ao ser aprovado nos exames com distinção, plenamente ou simplesmente, o aluno recebia um certificado de conclusão do curso assinado pela banca examinadora. O regimento previa, no seu artigo 77, que o professor que apresentasse mais alunos para se submeter aos exames poderia receber menção honrosa, caso seus alunos fossem aprovados. $\mathrm{O}$ presente dispositivo visava estimular uma competição entre os professores, mas ao mesmo tempo revela que não era comum os professores apresentarem muitos alunos para os exames. Ao consultar o relatório do ministro do Império, João Florentino Meira de Vasconcelos, de maio de 1885, encontrei uma informação muito significativa para compreender os impactos do regimento de 1883. Eis o texto do relatório:

"Por falta de alunos habilitados segundo as exigências do novo plano de estudos, não se efetivaram nas escolas públicas os exames de que trata o art. 68 do Regimento interno aprovado por ato de 6 de novembro de 1883 
e posto em execução no ano seguinte. Entretanto, à vista das provas de aproveitamento exibidas, no fim do ano letivo, pelos alunos das escolas da freguesia de Santa'Ana e pelos da $1^{\text {a }}$ de meninas da freguesia do Santíssimo Sacramento, é de esperar que no fim do corrente ano letivo se verifiquem os referidos exames" (BRASIL. Relatório do Ministro do Império, João Florentino Meira de Vasconcellos, de 1885, p. 43).

É possível imaginar que entre as 94 escolas públicas existentes não houve um aluno sequer em condições de prestar os exames? Na atualidade, um fato desses seria inconcebível. Sobre esse fato cabem os seguintes questionamentos: Será que o novo regimento introduziu mudanças tão significativas no cotidiano escolar? Será que nenhum dos professores estava preparado para dar conta dos acréscimos introduzidos nos conteúdos? Ou as bancas eram muito rigorosas? Certamente, o regimento tornou mais rigoroso o processo de ensino, por isso, os professores sentiram-se receosos em submeter seus alunos às bancas examinadoras. Ninguém quis ser o primeiro.

O fato de não ter havido alunos inscritos para os exames não aconteceu só por insegurança dos professores, pelo contrário, o episódio evidenciou a persistência de uma prática adotada por boa parte das famílias no período imperial. Refiro-me ao hábito de as famílias retiraram as crianças das escolas antes de elas concluírem o curso primário. Essa situação geralmente acontecia por dois fatores: $1^{\circ}$ - as famílias mais pobres retiravam seus filhos logo que eles dominavam os conhecimentos elementares da leitura, escrita e cálculo para inseri-los nos afazeres domésticos ou em outras atividades desenvolvida pelos pais visando aumentar a renda familiar. $2^{\mathbf{0}}$ - as famílias mais abastadas retiravam seus filhos, principalmente os meninos, logo que dominavam os processos de leitura e escrita, para submetê-los aos ensinamentos de professores particulares, com o propósito de prepará-los, o mais rápido possível, nas matérias específicas exigidas nos exames preparatórios para o ingresso nos cursos técnicos, secundários e superiores do Império. Para ingressar nos cursos técnicos, secundários e superiores, não se exigia o certificado de conclusão do ensino primário, mas, sim, a aprovação nos exames de admissão ou nos preparatórios. Apesar de as leis preverem a obrigatoriedade de ensino, na prática ela não era executada, daí a facilidade de os pais retirarem os filhos das escolas. Com a retirada dos alunos mais adiantados, diminuía-se o número dos prováveis candidatos a prestar os exames no final do ano letivo. De qualquer modo, o fato de não ter havido alunos prontos para os exames finais, no ano de implantação do novo regimento interno das escolas públicas da Corte, merece uma investigação mais aprofundada no futuro.

Os artigos 16 e 17 tratavam das possibilidades da existência de escolas mistas. $\mathrm{O}$ regimento apresentou duas situações novas em relação ao que vinha sendo praticado nas escolas públicas da Corte: $1^{\mathrm{a}}$ - os meninos entre 5 e 6 anos só poderiam frequentar escolas de meninas; $2^{\mathrm{a}}$ - os meninos poderiam frequentar as escolas de meninas até os 10 anos, no entanto, a frequência estava limitada à $1^{\mathrm{a}}$ classe, pois segundo o texto, caso o aluno ficasse pronto para a $2^{\mathrm{a}}$ classe, antes dos 10 anos, teria de frequentar uma escola de meninos. Todavia, não há qualquer menção no texto do regimento sobre a frequência de meninas nas escolas masculinas. Diante disso, podemos concluir que todos os procedimentos adotados visavam impedir que os professores ensinassem meninas. Os entraves colocados para a difusão das escolas mistas no Brasil contribuíram, significativamente, para retardar o avanço da escola primária no século XIX. Os adversários das escolas mistas, não eram apenas as pessoas simples, mas também figuras ilustres e, de elevados conhecimentos. Uma prova disso está no projeto substitutivo ao decreto de Leôncio de Carvalho, apresentado pela comissão de instrução da Câmara, sob a relatoria de Rui Barbosa. Conforme previsto pelo artigo $2^{\circ}, \S 3^{\circ}$ incisos XV: "as escolas elementares e médias que o 
governo declarar mistas, receberão indiferentemente alunos de um e outro sexo, não maiores de onze anos" e no XVI, "as escolas mistas, bem como os jardins de crianças e as escolas do sexo feminino, serão exclusivamente dirigidas por pessoas desse sexo. As escolas elementares do sexo masculino poderão ser indistintamente confiadas a professores e professoras" (BARBOSA, 1947, p. 95). Esses dois exemplos e muitos outros, que não cabem ser demonstrados aqui, evidenciam que o conjunto da legislação educacional produzida, a partir da segunda metade do século XIX, influenciou diretamente no processo de feminização do magistério da escola primária.

\section{O Sistema Disciplinar: castigos e prêmios}

A prática de castigos e prêmios era uma constante na escola primária do século XIX. Em estudo anterior (CASTANHA, 2009) tive a oportunidade de analisar essa problemática de forma mais abrangente percorrendo todo o período imperial. A tentativa de montagem de um sistema disciplinar equilibrado, certamente, acarretou muito tempo de estudos do inspetor Souza Bandeira e dos professores que contribuíram para construir o regimento. O sistema está detalhado entre os artigos 54 e 67 . O regimento cobrava dos professores, efetivos esforços, para despertar nos alunos o gosto para os estudos. $\mathrm{O}$ professor tinha como compromisso fazer de suas aulas momentos agradáveis, levando os alunos a desenvolver as atividades mais com o intuito de conhecer, do que por medo de serem punidos. O regimento permitia aos professores adaptar parte do sistema de punições sem, contudo, romper com as diretrizes impostas. No entanto, todas as adaptações no sistema disciplinar deveriam passar pela aprovação do inspetor geral.

O sistema disciplinar proposto pelo regimento, certamente, representou uma inovação no período, porém, de difícil execução e excessivamente burocrático. A proposta levava em conta a frequência, a instrução e o procedimento dos alunos. Para cada um desses componentes foram previstas notas que seriam atribuídas sobre o conjunto das atividades diárias. Tais notas poderiam ser positivas ou negativas, conforme a frequência escolar, empenho nos estudos e o comportamento dos alunos em sala de aula ou fora dela. As notas de todos os alunos seriam computadas diariamente, e, no final do mês, fazia-se a soma geral para verificar quais deles obtiveram mais pontos.

A proposta estabelecia um sistema de recompensas para valorizar os melhores alunos. Os três melhores alunos de cada classe seriam enaltecidos publicamente e teriam seus nomes inscritos no quadro de honra, podendo usar um distintivo durante as aulas, que os qualificava como chefes da classe. Além disso, tais alunos colaborariam com o professor para manter a disciplina e seriam ouvidos diariamente sobre o comportamento dos demais alunos da sua classe. O chefe da $3^{a}$ classe seria o auxiliar da biblioteca durante aquele mês. No entendimento do inspetor, tal mecanismo animaria os alunos a dedicaremse aos estudos, mantendo-os amáveis com os colegas e atentos às orientações dos professores.

Os castigos adotados pelo regimento são mais amenos que os instituídos pelo regimento de 1855. Enquanto o de 1855 permitia que o professor impusesse ao aluno indisciplinado a realização de tarefas fora do horário, ficar de joelhos com os braços abertos durante o tempo que o professor achasse necessário, punir os alunos por não aprender os conteúdos etc., o regimento de 1883 adotou penas mais brandas, evitando que os alunos fossem expostos a situações vexatórias. O que chama a atenção no sistema de pontuação adotado para mensurar as faltas dos alunos era o fato de que os alunos que agrediam um colega recebiam três pontos negativos, enquanto os que se portassem imoralmente receberiam seis pontos, e ainda, acumulavam as penas previstas para os agressores. Todo o sistema foi organizado, tendo como limites de pontos, três mais e três 
menos, porém, o gesto ou ato imoral recebia seis pontos negativos. Essa é outra evidência do peso dos aspectos morais naquela sociedade. $\mathrm{O}$ sistema de pontuação proposto não era um instrumento fácil de aplicar com justiça e nem de controlar de forma eficiente. Essa condição certamente tornava-se ainda mais complicada pelo fato de o regimento prever, no artigo 65, que o professor deveria estimular os alunos para acompanharem o controle do sistema e permitia-lhes a verificação periódica da situação de cada um. Certamente instaurava-se uma confusão em todas as vezes que o professor fazia o preenchimento dos formulários, pois enquanto alguns alunos solicitavam suas pontuações, outros denunciavam os colegas. Penso que o sistema proposto pelo regimento encontrou sérios problemas na sua execução, principalmente pelo fato de que o inspetor Souza Bandeira solicitou demissão do cargo em maio de 1884. A saída dele certamente, enfraqueceu o controle do sistema disciplinar.

\section{O Regimento e os Professores}

A sociedade imperial e toda a legislação educacional exigia que os professores fossem exemplos de virtudes para os alunos. Eles tinham um importante papel social a cumprir, como ficou evidenciado em Castanha e Bittar (2009). Daí a preocupação com a moralidade, amabilidade, cordialidade e pontualidade, expressas no artigo $3^{\circ}$ do regimento. Cada professor deveria ser um espelho para seus alunos. Por isso, deveriam receber bem os visitantes sendo pontuais nos registros e encaminhamentos das informações referentes às escolas. Conforme estabelecia o artigo 12, cabia ao professor manter sempre em dia e, de forma correta a escrituração escolar. Caso contrário seria responsabilizado pelas faltas, informações inexatas, erros, emendas ou rasuras.

Quanto às proibições, o artigo $4^{\circ}$ do regimento manteve exatamente as mesmas restrições previstas no regimento de 1855 . O texto enfatizou os dispositivos que proibiam os professores de desenvolver outras atividades remuneradas. Infelizmente, o salário não correspondia à excessiva carga de trabalho que lhes era imposta.

O sistema adotado para punir os professores infratores previsto entre os artigos $78 \mathrm{e}$ 85, baseou-se no estabelecido pelo Regulamento de 17 de fevereiro de 1854 . Tal adoção demonstra que aquele regulamento continuava em pleno vigor, mesmo depois do decreto $\mathrm{n}$. 7247, de 19 de abril de 1879, conhecido como Reforma Leôncio de Carvalho. Quanto às punições previstas para os casos de desobediência dos dispositivos do regimento, merecem destaque as seguintes: Multas - aplicadas nos casos de descuido com a burocracia escolar (envio dos mapas e registro dos livros), os desleixos com a higiene e o não cumprimento do plano de ensino; Repreensão - Os professores seriam repreendidos nos casos de não cumprirem os horários estabelecidos, nos descuidos com a higiene da escola e dos alunos e pela não observância do sistema disciplinar. Tanto as multas quanto as advertências constariam nas folhas de registro dos professores.

O documento deixa claro que o professor era o responsável pela preservação de todos os objetos da escola, sendo obrigado a indenizar o Estado, caso sumissem ou fossem destruídos alguns dos móveis e utensílios, por negligência sua. Conforme previa o artigo 34, as escolas receberiam um valor mensal para a aquisição de materiais escolares, materiais de limpeza e outros objetos necessários ao seu bom funcionamento. A base para o cálculo dos recursos foi estabelecida no artigo 94. Segundo previsto no referido artigo, o montante dos recursos que cada escola recebia era calculado com base no número de alunos matriculados em cada uma delas. O regimento estabeleceu que o percentual fosse calculado tendo como referência dois terços das matrículas. Tal critério foi adotado porque, na época, a média dos alunos frequentes girava entre 60 e $70 \%$, dos alunos matriculados. 
Pelo disposto fica evidenciado que os recursos públicos já eram repassados diretamente para as escolas.

Conforme determinava o artigo 35, os alunos receberiam os livros didáticos para os exercícios escolares, mas não poderiam levá-los para casa, sendo de uso exclusivo na escola. Melhor para os professores, pois assim facilitava o controle e a preservação dos mesmos. Também era de inteira responsabilidade dos professores manterem as escolas limpas e arejadas, conforme determinava o artigo 36. Para tanto, deveriam manter as janelas abertas, varrê-las diariamente e lavá-las ao menos uma vez por mês. Certamente, os professores lavavam as escolas mais de uma vez por mês, pois na época todos os caminhos para se chegar às escolas eram de terra. Conforme determinava o artigo 92, os professores poderiam morar nas casas escolares, desde que as necessidades das escolas não fossem sacrificadas à comodidade dos professores ou de suas famílias.

\section{Biografia de Souza Bandeira}

Antonio Herculano de Souza Bandeira Filho foi inspetor geral de instrução pública na Corte, entre 2 de maio de 1883 e 24 de maio de 1884. Politicamente era ligado ao grupo dos liberais. Souza Bandeira nasceu no Recife, em 1854. Formou-se em direito pela Faculdade de Recife em 1874, e pouco tempo depois assumiu um cargo no Ministério da Justiça. Na Corte, foi professor interino na Escola Normal, assumindo a cadeira de lógica e direito natural e público. Conforme informou o professor Afonso Carlos Moreira, no seu relatório apresentado à Congregação da Escola Normal, em 11 de fevereiro de 1882, encontrava-se na Europa desde o dia 2 de agosto do ano passado, o "ilustrado colega, o Sr. Dr. Antonio Herculano de Souza Bandeira Filho, a quem o governo imperial incumbiu de estudar, nos países mais adiantados dessa parte do mundo, a organização das escolas normais e instituições análogas" (BRASIL. Escola Normal da Corte. Relatório de 1882 p. 2). Por sua vez, o Ministro do Império Rodolfo Dantas, informou que o

\footnotetext{
Dr. Antonio Herculano de Souza Bandeira Filho, já encarregado de visitar as escolas normais nos países onde houver de se demorar durante a sua viagem pela Europa, incumbiu também, por Aviso de 2 de março, de visitar naqueles países, e particularmente na França, Bélgica, Alemanha e Suíça, os jardins de infância, e apresentar as bases para levar-se a efeito entre nós do modo mais conveniente a criação de semelhantes jardins, tendo muito em vista, além do que se referir ao ensino, a formação do professorado respectivo (BRASIL. Relatório do Ministro do Império, Rodolfo Epifânio de Souza Dantas de 1882, p. 36).
}

Logo que regressou da Europa, foi nomeado inspetor de instrução pública da Corte. À frente da inspetoria, tomou uma série de iniciativas para organizar a instrução pública, como a reorganização do regimento interno das escolas, a organização das bibliotecas escolares e a distribuição dos livros didáticos, a reorganização das conferências pedagógicas. Ao deixar a inspetoria, foi nomeado presidente da Província da Paraíba, entre os anos de 1885 e 1886 e, em 1889, administrou a Província de Mato Grosso, ficando no poder até a queda do Império. Tanto na Paraíba, quanto em Mato Grosso, Souza Bandeira reformou a instrução pública. Por onde passou, demonstrou-se preocupado e empenhado com as questões educacionais, produzindo uma legislação equilibrada entre os interesses dos alunos, professores, a sociedade e o Estado. Lamentavelmente, faleceu em 1890, na cidade de Nova Friburgo-RJ, com apenas 46 anos. 


\section{Conclusões}

Em estudo anterior afirmei que "toda lei é uma síntese de múltiplas determinações". Quando a lei é colocada em execução, "as contradições se revelam, pois, interesses particulares ou de grupos são contestados, as resistências se acentuam", as falhas aparecem. As "contradições aceleram o debate e novas alternativas são propostas, novas leis são aprovadas". Ou seja, com as leis também acontece o processo de tese, antítese e síntese. Segundo Gramsci, o homem e a sociedade são um constante devir. Nesse constante devir dos homens e da sociedade, as "leis têm um papel fundamental como instrumento de mediação das relações sociais, das contradições presentes entre os grupos, constituindo-se em mecanismo de disciplinarização dos conflitos e contradições sociais". As leis são, portanto, sínteses de múltiplas determinações sociais e estão em constante transformação. (2011b, p. 316-7).

Essa dinâmica das leis pode ser evidenciada no processo de implantação do Regimento Interno das Escolas de 1883. Toda lei ao ser posta em execução cria expectativas. Em se tratando de leis educacionais, avalia-se a eficiência pelos resultados práticos que ela apresenta.

Vimos pelo relatório do ministro do Império, apresentado em 1885, que no decorrer de 1884, os professores não apresentaram alunos para realizar os exames finais como previa o Regimento de 1883. Na oportunidade, o ministro estranhou, mas mantinha a esperança que nos anos seguintes os resultados iriam aparecer. Ao consultar o relatório do Ministro Ferreira Vianna, apresentado em 1889 foi possível perceber que o problema não havia sido resolvido. As leis garantiam aos professores o direito de vitaliciedade depois de cinco anos de exercício ininterrupto. Garantiam também, gratificações após 10, 15 ou 20 anos de exercício da profissão. Ao analisar os pedidos de vitaliciedade e de gratificações, Ferreira Vianna, vinculado ao grupo dos conservadores, entendeu que deveria ser rigoroso e cumprir a lei. Tanto o Regulamento de 1854, quanto o de 1877, previam benefícios aos professores que demonstrassem assiduidade, proficiência e zelo no desempenho de suas funções. Todavia, os dados referentes ao número de alunos submetidos a exames finais e aprovados, no final do ano letivo, não justificavam a concessão dos benefícios para a maioria dos professores. Diante disso, o Ministro baixou uma medida declarando que ficava "dependente do aproveitamento dos alunos das escolas primárias a declaração da vitaliciedade dos professores públicos, assim como o reconhecimento do direito às gratificações adicionais e à conservação desta vantagem" (BRASIL. Decisão n. 7 do Ministério do Império de 1889 , p. 5). A proposta não só vinculava a concessão de novos benefícios, mas também a permanência daqueles que já haviam sido concedidos ao número de alunos aprovados nos exames previstos pelo artigo 68 do Regimento.

Segundo consta no seu relatório, a decisão despertou "queixumes por parte dos professores". Diante das reclamações, o Ministro chamou os professores para uma reunião, "a fim de ouvi-los sobre o assunto". Sobre tal encontro, Ferreira Vianna destacou:

Nesta reunião, devidamente esclarecidos, puderam eles reconhecer não só que a resolução do governo fora adotada a bem do ensino e dos créditos do professorado, diante do fato surpreendente de terem no longo decurso de cinco anos somente treze professores apresentado alunos aos exames, apenas em o número de 37, dos quais só 8 lograram ser habilitados, o que sem dúvida não justifica os sacrifícios que ao Estado custa o ensino oficial; mas também que as disposições do atual Regimento interno das escolas não embaraçam o preparo dos alunos para os exames em que o mesmo Regimento exige que se demonstre o proveito do ensino 
(BRASIL. Relatório do Ministro do Império, Antônio Ferreira Vianna. de 1889 , p. 22-3).

Os números da educação da Corte no período ajudam a entender a posição do ministro. Entre 1884 e 1889, havia 94 escolas públicas na Corte, todas em atividade; o número de alunos matriculados era superior a oito mil anualmente. Naquele espaço de tempo, somente 37 alunos foram inscritos para os exames finais, dos quais 25 foram reprovados, 4 não compareceram e, apenas 8 foram aprovados. Temos que admitir, os dados davam razão ao Ministro. Ele, de fato, tinha razão em cobrar providências dos professores. A opção encontrada foi ameaçar a supressão dos direitos adquiridos pela categoria.

Meses depois, uma nova decisão foi baixada pelo novo Ministro do Império, Franklin Américo de Meneses Dória - o Barão de Lorena, vinculado ao grupo liberal. A decisão declarava "sem efeito o Aviso de 6 de fevereiro que tornou dependente do aproveitamento dos alunos a declaração da vitaliciedade dos professores públicos das escolas primárias, assim como o reconhecimento do direito às gratificações adicionais, e a conservação desta vantagem" (BRASIL. Decisão n. 55 do Ministério do Império de 1889, p. 43). Ao que parece, os "queixumes" dos professores persistiram depois da reunião com o Ministro Ferreira Vianna, pressionando, o novo ministro a dar uma solução para o problema. Franklin Dória, depois de recuperar toda a legislação que tratava da concessão da vitaliciedade e dos benefícios por tempo de serviço, sustentou que a decisão de 6 de fevereiro não tinha base legal para ser executada.

Esse episódio evidencia a dinâmica das leis, seus aspectos contraditórios, sua riqueza enquanto fonte histórica. Ele mostra que é necessário buscar o pleno conhecimento do contexto de discussão, aprovação e execução das leis. É preciso considerar a linguagem, a tradição, o desenvolvimento econômico e social, as forças políticas etc. Ao adotarmos tais procedimentos evitaremos análises anacrônicas e diminuiremos os riscos de fazermos julgamentos tendenciosos ou preconceituosos sobre os atos humanos do passado.

\section{Referências}

BARBOSA, Rui. Reforma do ensino primário e várias instituições complementares da instrução pública. Rio de Janeiro: Ministério da educação e Saúde, 1947, (Obras completas de Rui Barbosa, Vol. X, Tomo IV).

Reforma do ensino primário e várias instituições complementares da instrução pública. Rio de Janeiro: Fundação Casa de Rui Barbosa, 1982.

BRASIL. Decreto n. 1331-A de 17 de fevereiro de 1854 do Ministério do Império. Aprova o Regulamento para a reforma do ensino primário e secundário do Município da Corte. Coleção das Leis do Império do Brasil de 1854 - Tomo XVII. Parte II. Rio de Janeiro: Tipografia Nacional, 1854, p. 45-69.

Portaria do Ministério do Império de 20 de outubro de 1855. Aprova e Manda que se observe, para execução do parágrafo $8^{\circ}$ do Artigo $3^{\circ}$ do Regulamento que baixou com o Decreto N. 1.331 A de 77 de Fevereiro de 1854, o Regimento Interno para as Escolas Públicas de instrução primária. Coleção das Decisões do Governo do Império do Brasil de 1855 - Tomo XVIII. Rio de Janeiro: Tipografia Nacional, 1855, p.344-352.

Decreto n. 6479 de 18 de janeiro de 1877 do Ministério do Império. Manda executar o Regulamento para as Escolas públicas de instrução primária do município da 
Corte. Coleção das Leis do Império do Brasil de 1877 - Tomo XL. Parte II. Rio de Janeiro: Tipografia Nacional, 1877, p. 27-35.

. Decreto n. 7247 de 19 de abril de 1879 do Ministério do Império. Reforma $o$ ensino primário e secundário no município da Corte e o superior em todo o Império. Coleção das Leis do Império do Brasil de 1879 - Parte II Tomo XLII. Rio de Janeiro: Tipografia Nacional, 1880, p. 196-217.

. Decreto n. 7684 de 6 de março de 1880. Cria no município da Corte uma Escola Normal primária. Coleção das Leis do Império do Brasil de 1880. Tomo XXVII, parte II. Rio de Janeiro: Tipografia Nacional, 1881, p. 187-203.

Decisão n. 4 do Ministério do Império de 9 de janeiro de 1882. Aprova o programa de ensino e o horário para serem provisoriamente observados nas escolas públicas de instrução primária do primeiro grau do município da Corte. Coleção das Decisões do Governo do Império do Brasil de 1882. Rio de Janeiro: Tipografia Nacional, 1883, p. 5-11. Caderno de Aditamentos.

Decisão do Ministério do Império de 12 de janeiro de 1882. Regulamento para as Caixas Econômicas Escolares. Publicado como anexo C, do Relatório do Ministério do Império referente ao ano de 1881. Apresentado a Assembleia Geral Legislativa em 09 de janeiro de 1882 pelo Ministro Manoel Pinto de Souza Dantas. Rio de Janeiro: Tipografia Nacional, 1882, p. 1-14.

Escola Normal da Corte. Relatório apresentado à Congregação da Escola Normal, em 11 de fevereiro de 1882 pelo professor Afonso Carlos Moreira. Publicado como anexo A4 do Relatório do Ministro dos Negócios do Império, Rodolfo Epifânio de Souza Dantas. Apresentado à Assembleia Geral Legislativa em 29 de maio de 1882. Rio de Janeiro: Tipografia Nacional, 1882.

- Relatório do Ministro dos Negócios do Império, Rodolfo Epifânio de Souza Dantas. Apresentado à Assembleia Geral Legislativa em 29 de maio de 1882. Rio de Janeiro: Tipografia Nacional, 1882.

Decisão do Ministério do Império de 17 de maio de 1883. Regulamento para a criação em cada escola pública de bibliotecas escolares. Publicado como anexo C, do Relatório do Ministério do Império referente ao ano de 1883. Apresentado a Assembleia Geral Legislativa em 03 de maio de 1884 pelo Ministro Francisco Antunes Maciel. Rio de Janeiro: Tipografia Nacional, 1884, p. 1-2.

Decisão n. 77 do Ministério do Império de 6 de novembro de 1883. Aprova o regimento interno para as escolas públicas primárias do $1^{o}$ grau do município da Corte. Coleção das Decisões do Governo do Império do Brasil de 1884. Rio de Janeiro: Tipografia Nacional, 1884, p. 76-91.

Relatório do Ministro dos Negócios do Império, João Florentino Meira de Vasconcellos. Apresentado à Assembleia Geral Legislativa em 29 de maio de 1885. Rio de Janeiro: Tipografia Nacional, 1885.

Decisão n. 7 do Ministério do Império de 6 de fevereiro de 1889. Declara que deve ficar dependente do aproveitamento dos alunos das escolas primárias a declaração da vitaliciedade dos professores públicos, assim como o reconhecimento do direito às gratificações adicionais e à conservação desta vantagem. Coleção das Decisões do Governo do Império do Brasil de 1889. Rio de Janeiro: Imprensa Nacional, 1889. 
BRASIL. Relatório do Ministro dos Negócios do Império, Antônio Ferreira Vianna. Apresentado à Assembleia Geral Legislativa em 15 de maio de 1889. Rio de Janeiro: Imprensa Nacional, 1889.

Decisão n. 55 do Ministério do Império de 10 de outubro de 1889. Declara sem efeito o Aviso de 6 de fevereiro que tornou dependente do aproveitamento dos alunos a declaração da vitaliciedade dos professores públicos das escolas primárias, assim como o reconhecimento do direito às gratificações adicionais, e a conservação desta vantagem. Coleção das Decisões do Governo do Império do Brasil de 1889. Rio de Janeiro: Imprensa Nacional, 1889.

CASTANHA, André Paulo. Edição crítica da legislação educacional primária do Brasil imperial: a legislação geral e complementar referente à Corte entre 1827 e 1889. Campinas: Faculdade de Educação, 2011a (Relatório de Estágio de Pós-doutorado).

"O uso da legislação educacional como Fonte: orientações a partir do marxismo". In: Revista HISTEDBR On-line, Campinas, número especial, p. 309-331, $\mathrm{abr} / 2011 \mathrm{~b}$.

"A prática dos castigos e prêmios na escola primária do século XIX: do legal ao real". Educere Et Educare - Revista de educação. Cascavel-PR: Edunioeste, 2009. v. 4 n. 8, jul/dez, 2009, p. 245-259. Disponível também em: http://erevista.unioeste.br/index.php/educereeteducare/article/view/3724/2926

e BITTAR, Marisa "O papel dos professores na formação social brasileira: 18271889”. In: Revista HISTEDBR Online, v. 34, p. 37-61, jun. 2009 - ISSN: 1676-2584. Disponível em: http://www.histedbr.fae.unicamp.br/revista/edicoes/34/index.html

MUNICÍPIO da Corte. Inspetoria Geral de Instrução Primária e Secundária. Relatório do Inspetor Geral Antonio Herculano de Souza Bandeira Filho, de 15 de fevereiro de 1884. Apresentado ao Ministério dos Negócios do Império e publicado como anexo C-7 do Relatório do Ministro dos Negócios do Império, Francisco Antunes Maciel, apresentado à Assembleia Geral Legislativa, em 3 de maio de 1884. Rio de Janeiro: Tipografia Nacional, 1884.

\footnotetext{
${ }^{1} \mathrm{O}$ presente documento foi objeto de análise no estudo intitulado: Edição crítica da legislação educacional primária do Brasil imperial: a legislação geral e complementar referente à Corte entre 1827 e 1889 , apresentado com Relatório de Estágio de Pós-doutorado à Faculdade de Educação da Unicamp, em 2011, sob a supervisão do professor Dermeval Saviani. Naquele texto, a análise foi desenvolvida na forma de notas críticas, neste em forma de artigo.

${ }^{2}$ Professor do Colegiado de Pedagogia e do Programa de Mestrado em Educação da Unioeste - Campus de Francisco Beltrão - PR. Membro do Grupo de Pesquisa: História, Sociedade e Educação no Brasil HISTEDOPR - GT da Unioeste. Historiador e mestre em Educação pela UFMT, Doutor em Educação pela UFSCar e Pós-doutor na área de Filosofia e História da Educação pela UNICAMP. E-mail: andrecastanha@brturbo.com.br
} 